\title{
Screening of additives to reduce grain damage risk on unhairing by proteinase $\mathrm{K}$
}

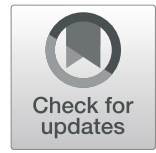

Mei Chen ${ }^{1}$, Mingfang Jiang ${ }^{2}$, He Li ${ }^{1}$ and Haiming Cheng ${ }^{1,3^{*}}$ (D)

\begin{abstract}
Enzymatic unhairing is a cleaner strategy for leather-making. It is a potential alternative to the traditional hairburning process. However, several shortcomings, such as uncontrolled enzymatic reaction, and risk of grain looseness and damage have restricted the broad application of enzymatic unhairing. In this work, metal ions and organic additives were screened for lessening the hydrolytic activity of proteinase $\mathrm{K}$ to collagen fiber. Then, the selected additives were applied to the enzymatic unhairing process for bovine hide. The results showed that a suitable concentration of metal ions (CU (II), Fe (III) and AI (III)) and organic additives (salicylate, laurate, adipate, gallate and epicatechin (ECG)) could diminish approximately $35 \%$ of the hydrolytic activity of proteinase $\mathrm{K}$ to collagen fibers. Then, the additives were applied for the bovine hide enzymatic unhairing process. Hydroxyproline determination in the unhairing float shows that applying additives could reduce collagen hydrolysis. The morphology results showed that the grain damage could be significantly reduced with the addition of the screened additives in the proteinase K enzymatic unhairing system, whereas the addition of ECG and gallate significantly slowed down the unhairing speed. This outcome provides new potential to reduce the risk of grain damage in enzymatic unhairing process.
\end{abstract}

Keywords: Enzymatic unhairing, Grain damage, Proteinase K, Inhibitor, Leather making

\section{Introduction}

Unhairing is an essential procedure for leather-making process. Traditional lime unhairing generates a major amount of pollution in beamhouse. Enzymatic unhairing has been considered as an important hair-saving alternative to the traditional hair-burning process [1]. However, the enzymatic process leads to grain loosen effect on the pelt and unstable quality leather due to the risk of enzymatic injury to the leather and collagen fibers despite their environmental benefits [2,3]. Several approaches have been described for safe enzymatic unhairing and reducing the risk of the grain damage [4-9]. The components of enzyme preparations commonly used for unhairing are complicated, and may be classified as

\footnotetext{
* Correspondence: chenghaiming@scu.edu.cn

'Key Laboratory of Leather Chemistry and Engineering of Ministry of

Education, Sichuan University, Chengdu 610065, China

${ }^{3}$ National Engineering Laboratory for Clean Technology of Leather

Manufacture, Sichuan University, Chengdu 610065, China

Full list of author information is available at the end of the article
}

caseinase and collagenase due to their hydrolytic capacity for casein or native collagen [10]. Natural collagen molecules can only be hydrolyzed by the collagenase components, which are members of the family of matrix metalloproteinases (MMPs) that are capable of degrading the extracellular matrix [11]. Collagenase components play the main role in grain damage and grain sueding in enzymatic unhairing [12]. Therefore, the inhibition, or even complete removal, of the collagenase components in the enzymatic unhairing process is a key strategy for achieving safe enzymatic unhairing. In our previous study, we found that bovine hide that was enzymatic unhaired at $20-25^{\circ} \mathrm{C}$ was much safer than that unhaired at higher temperatures $[8,13]$. However, the enzymatic process controlling the temperature was less efficient, leading to the unhairing process being extended to $12-16 \mathrm{~h}$, which is twice as long as enzymatic unhairing at $35^{\circ} \mathrm{C}$. A risk of grain damage was noted when temperature was out of control during hot seasons. Another approach involves screening effective 
collagenase inhibitors for preventing the exclusive hydrolysis of collagen by enzymes [14]. Literature data show that collagenase inhibitors have the zinc binding function, such as the derivatives of carboxylate, hydroximate, and polyphenol [15-19]. In addition, many metal ions illustrate inhibition effect on serine proteases and MMPs since the structural stability of protein could be influenced significantly under the metal ion environment [20, 21]. The addition of certain amount of bivalent metal ions (Mg (II), Mn (II), and Zn (II)) demonstrated an efficient rate of enzymatic unhairing by AS1.398 protease on bovine hide with less damage to the grain and the hair pores [14].

Proteinase K (EC 3.4.21.14) is a serine protease originally isolated from Tritirachium album Limber, which can be obtained easily with high fermentation level [22]. Two $\mathrm{Ca}$ (II) ion binding-sites are near the active center of proteinase $\mathrm{K}$, which plays a key role in maintaining enzyme activity and stabilizing its conformation structure [23]. In comparison with others proteases, proteinase K shows excellent activity with the existence of anionic detergent sodium dodecyl sulfate and nonionic detergent Triton-100, which are commonly applied as the degreasing agent in leather making process [24]. In our previous work, proteinase $\mathrm{K}$ illustrated unhairing abilities on bovine hide. However, due to its collagen hydrolysis characteristics, proteinase $\mathrm{K}$ is also likely to cause excessive collagen hydrolysis during the process, resulting in grain loosening and even damage to the finished leather. Here, $\mathrm{Cu}$ (II), Co (II), Ba (II), Fe (III) and $\mathrm{Al}$ (III) metal ions, and cost effective and easily obtained organic ligands, such as salicylate, laurate, adipate, gallate, and epicatechin, were investigated. The effect of these additives on the hydrolytic activity of proteinase $\mathrm{K}$ to casein and collagen fibers was determined to screen the additives for effectively inhibiting the hydrolytic activity to collagen fibers while maintaining its casein hydrolytic activity. Then, the additives that could effectively inhibit hydrolytic activity to collagen fibers, but not significantly hinder hydrolytic activity to casein were applied for the enzymatic unhairing process on bovine hide.

\section{Materials and methods}

\subsection{Materials}

The salt cured bovine hides were obtained from local tannery (Chengdu, China). Proteinase K (liq.) (EC 3.4.21.14) was obtained from Yanmei Biotech (Jiangsu, China). Bovine collagen fiber and Folin-phenol reagent was prepared in our lab. $\mathrm{Al}_{2}\left(\mathrm{SO}_{4}\right)_{3}, \mathrm{FeCl}_{3}, \mathrm{CuSO}_{4}, \mathrm{BaCl}_{2}$, $\mathrm{CoSO}_{4} \cdot 7 \mathrm{H}_{2} \mathrm{O}$, sodium gallate, sodium adipate, sodium laurate, soudium salicylate, epicatechin (ECG) were purchased from Kelong Chemicals (Chengdu, China) and all the other chemicals and reagents were used without further treatment.

\subsection{Enzymatic activity assays [14]}

For collagen fiber hydrolysis, $10 \mathrm{mg}$ of insoluble collagen fibers was dispersed in $3.8 \mathrm{~mL}$ of $50 \mathrm{mM}$ Tris- $\mathrm{HCl}$ buffer $\left(\mathrm{pH} 7.5\right.$ ) at $40^{\circ} \mathrm{C}$; then, $200 \mu \mathrm{L}$ of $0.5 \mathrm{mg} / \mathrm{mL}$ proteinase $\mathrm{K}$ solution was added for a hydrolytic reaction for $60 \mathrm{~min}$ with moderate shaking. The reaction was then terminated by adding $1.0 \mathrm{~mL}$ of $0.1 \mathrm{M}$ acetic acid. The activity was tested as follows: $0.5 \mathrm{~mL}$ of the supernatant of the reaction solution and $1 \mathrm{~mL}$ of $1 \%$ ninhydrin solution were incubated at boiling water with vigorous mixing for $15 \mathrm{~min}$. After cooling to ambient temperature, it was calibrated to $25 \mathrm{~mL}$ by double distilled water. Optimal density was measured by a 9100 UV-vis spectrophotometer (Ruili Analytical Instrument, Shanghai, China) at $570 \mathrm{~nm}$ to determine the concentration of the amino acid on the basis of the previously established calibration curve from the standard isoleucine solution. The activity unit is expressed as $\mu \mathrm{mol}$ of the equivalent isoleucine released per min per $\mathrm{mg}$ of protein. All the experiments for catalytic activity test were measured in triplicate.

For casein hydrolysis, the hydrolytic activity of proteinase $\mathrm{K}$ to substrate casein was determined at $680 \mathrm{~nm}$ according to the conventional casein-Folin phenol assay [25]. The enzymatic reaction was achieved by incubating the mixture of enzyme and substrate $(\mathrm{pH} 7.2)$ at $40^{\circ} \mathrm{C}$ for $10 \mathrm{~min}$. One unit (U) of enzyme activity is expressed as the amount of enzyme that released $1 \mu \mathrm{mol}$ of tyrosine per min under assay conditions. All the experiments for catalytic activity test were measured in triplicate.

\subsection{Effect of additives on hydrolytic activities of proteinase $\mathrm{K}$}

We incubated $10 \mathrm{mg}$ of insoluble collagen fibers in the solution consisting of $3.8 \mathrm{~mL}$ of $50 \mathrm{mM}$ Tris- $\mathrm{HCl}$ buffer $(\mathrm{pH} 7.5)$ and a set concentration of the additive agents at $40{ }^{\circ} \mathrm{C}$ for $5 \mathrm{~min}$, after which $200 \mu \mathrm{L}$ of $0.5 \mathrm{mg} / \mathrm{mL}$ proteinase $\mathrm{K}$ solution was added. The hydrolytic ability of the enzyme to the substrate collagen fiber and casein under the additive agent environment was determined on the basis of the above mentioned enzymatic activity assays. All the experiments were run in triplicate. Relative activity was used to evaluate the influence of the additive agents. It is calculated by Eq. (1):

$$
\begin{aligned}
\text { Relative activity }(\%)= & \frac{\text { activity of experimental }}{\text { activity of control }} \\
& \times 100 \%
\end{aligned}
$$

\subsection{Enzymatic unhairing process}

The soaked and fleshed bovine hide was symmetrically cut into $25 \times 30 \mathrm{~cm}$ pieces by the backbone, with the longer side parallel to the backbone. The enzyme unhairing process was carried out at $35^{\circ} \mathrm{C}$ with $150 \%$ 
float at $\mathrm{pH}$ 8.0, which was adjusted using sodium carbonate. Then, a weighed amount of agents (to ensure the metal ions or organic groups at their set concentration) was added and ran at $6 \mathrm{rpm}$ for $30 \mathrm{~min}$. Then, a dosage of $150 \mathrm{U} / \mathrm{g}$ of hide proteinase $\mathrm{K}$ was added to initiate the unhairing. The drum ran for $60 \mathrm{~min}$, and then it was stopped for $30 \mathrm{~min}$, after which it was run $5 \mathrm{~min}$ every $30 \mathrm{~min}$. The unhairing extent was observed during the process, and the float was periodically taken out to measure the content of total protein (TP) and hydroxyproline (Hyp). The unhaired pelt was then processed by the conventional beamhouse and chrome tanning process.

\subsection{Determination of total protein (TP) content}

After centrifugation for $10 \mathrm{~min}$ at $3000 \mathrm{rpm}$, the supernatant of the unhairing float was diluted to a suitable concentration in which the content of the TP was measured at $750 \mathrm{~nm}$ by the Lowry assay [26], using bovine serum albumin (BSA) as the protein standard. The measurements were performed in triplicate.

\subsection{Determination of hydroxyproline (Hyp) content}

The supernatant of the unhairing float was diluted to a suitable concentration, in which the content of Hyp was determined by the chloramine-T method at $558 \mathrm{~nm}$ [27]. Hyp content in the float reflected hydrolyzed collagen during the unhairing process. The measurements were performed in triplicate.

\subsection{Scanning electron microscopy (SEM)}

Samples were cut off from the enzymatic unhaired pelt, fixed in a neutral formaldehyde solution (10\%) over $48 \mathrm{~h}$, and then lyophilized. The lyophilized samples were coated with gold and observed by a JSM-7500F scanning electron microscope (JEOL, Japan) at a $15 \mathrm{kV}$ accelerating voltage.

\section{Results and discussion}

\subsection{Screening of additives}

\subsubsection{Metal ions}

At $40^{\circ} \mathrm{C}$, various concentrations of metal ions $(0-10$ $\mathrm{mM}$ ) were added into the enzymatic hydrolysis system to evaluate their influence in hydrolyzing collagen fibers and casein, respectively; the results are shown in Fig. 1.

$\mathrm{Cu}$ (II) showed an inhibition effect on proteinase $\mathrm{K}$ for hydrolyzing both casein and collagen fiber. The relative activity to casein decreased to $90 \%$ as the concentration of $\mathrm{Cu}$ (II) rose to $6.0 \mathrm{mM}$. When the concentration of the $\mathrm{Cu}$ (II) was higher than $6.0 \mathrm{mM}$, the caseinase inhibition effect was rapidly increased. When the concentration of $\mathrm{Cu}$ (II) was $8.0 \mathrm{mM}$, the relative activity of caseinase remained at only $40 \%$. However, the relative activity of collagenase was maintained stable at $40 \%$ as the concentration of $\mathrm{Cu}$ (II) rose to $1.0-20 \mathrm{mM}$. The results showed that when the concentration of $\mathrm{Cu}$ (II) in the enzyme system was $5.0-6.0 \mathrm{mM}$, the relative activity of caseinase remained at approximately $90 \%$, whereas only $40 \%$ of collagenase activity was maintained, implying that proteinase $\mathrm{K}$ could be effectively applied for reducing grain damage risk in enzymatic unhairing by controlling the concentration of $\mathrm{Cu}$ (II) to $5.0-6.0 \mathrm{mM}$. The inhibition effect of Co (II) and Ba (II) on the caseinase component of proteinase $\mathrm{K}$ increased with the increase in ion concentration, and we did not observe much of an inhibition effect on hydrolyzing the collagen

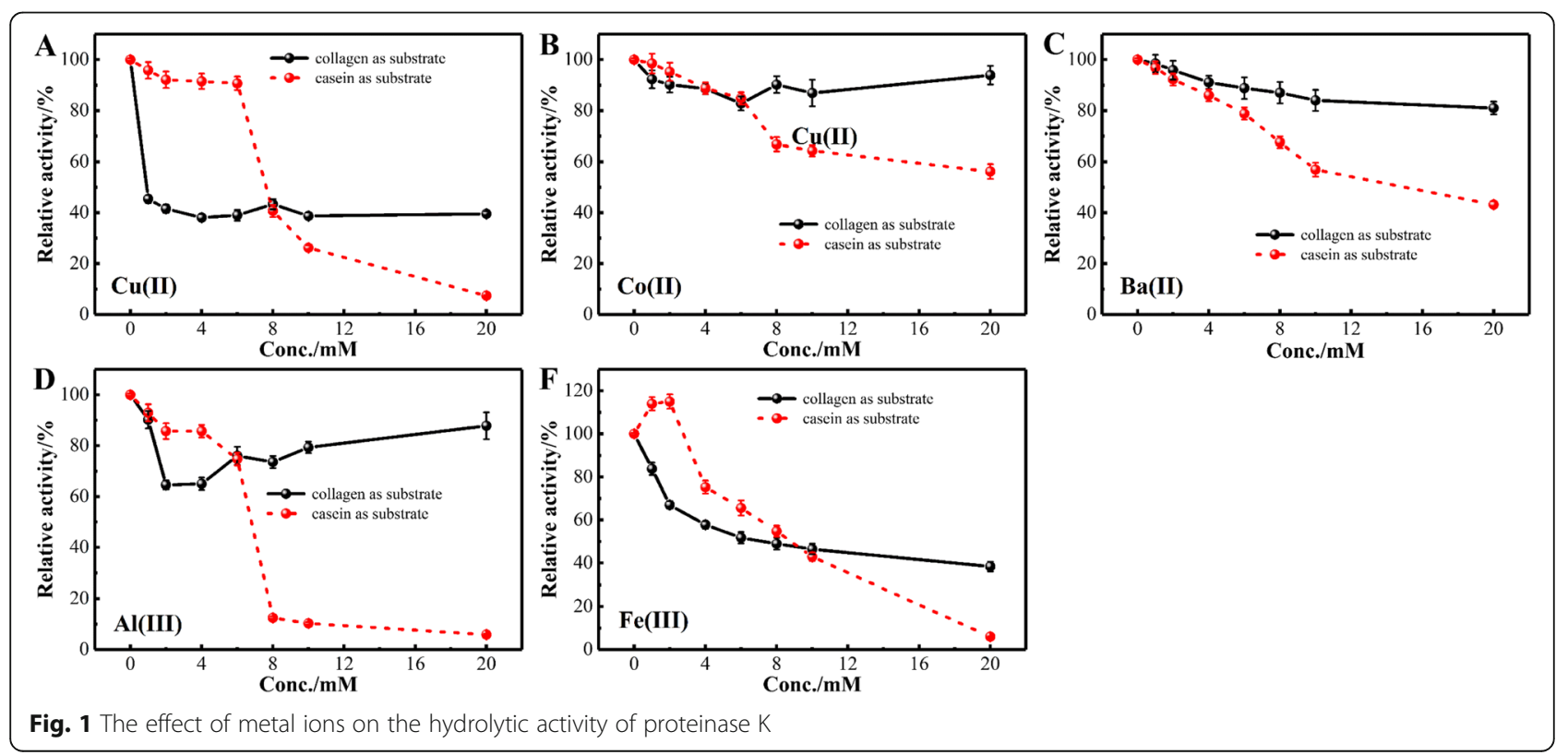


fiber. At the experimental concentrations, more than $80 \%$ of the relative activity of collagenase could be maintained. The results suggested that the addition of Co (II) or $\mathrm{Ba}(\mathrm{II})$ may have had no effect on reducing grain damage in enzymatic unhairing.

$\mathrm{Al}(\mathrm{III})$ showed a radical inhibition effect on the caseinase component of proteinase $\mathrm{K}$ with the increase in concentration to $8.0 \mathrm{mM}$, at which only $10 \%$ of the relative activity was maintained. $\mathrm{Al}(\mathrm{III})$ also showed an inhibition effect on the hydrolysis of collagen fiber. When the concentration of $\mathrm{Al}(\mathrm{III})$ was at $4.0 \mathrm{mM}, 64.6 \%$ of the relative activity of collagenase could be maintained while $85.7 \%$ of the relative activity of caseinase remained, indicating that the addition of $\mathrm{Al}(\mathrm{III})$ could reduce the risk of grain damage during enzymatic unhairing by proteinase $\mathrm{K}$. However, when the concentration of $\mathrm{Al}(\mathrm{III})$ ion was higher than $8.0 \mathrm{mM}$, only $10 \%$ of the relative activity of caseinase could be maintained, which could drastically reduce the unhairing rate. The hydrolytic activity of proteinase $\mathrm{K}$ to collagen fiber decreased with the increase in concentration of $\mathrm{Fe}(\mathrm{III})$. The hydrolytic activity of caseinase was activated when the concentration of Fe(III) ion was at $1.0-2.0 \mathrm{mM}$, after which the hydrolytic activity of caseinase decreased with the increase of $\mathrm{Fe}(\mathrm{III})$ ion. For comprehensive consideration, controlling the concentration of $\mathrm{Fe}(\mathrm{III})$ at $2.0 \mathrm{mM}$, the inhibition effect on collagenase was larger than that on caseinase, illustrating the potential to maintain effective enzymatic unhairing while reducing the risk of grain damage.

The $\mathrm{Ca}(\mathrm{II})$ ion in the active site of protease $\mathrm{K}$ might be partly or completely substituted by other bivalent metal ions that influenced its catalytic activity. At higher concentrations, metals ions might have bound to the active site of protease $\mathrm{K}$ and resulted in the significantly reduced catalytic activity [28-30]. In addition, metal ions such as $\mathrm{Fe}(\mathrm{III})$ and $\mathrm{Al}(\mathrm{III})$ may diminish the affinity between the substrate of collagen fiber and proteinase K [31].

\subsubsection{Organic additives}

At $40^{\circ} \mathrm{C}$, various concentrations of organic additives $(0-20 \mathrm{mM})$ were added into the proteinase $\mathrm{K}$ hydrolytic system to evaluate the influence in hydrolyzing collagen fibers and casein, respectively. The results are shown in Fig. 2.

ECG showed a notable inhibition effect of the collagenase component of proteinase $\mathrm{K}$. At the experimental concentration range of added ECG, approximately 60\% of the relative activity of the collagenase component was maintained, whereas its inhibition effect of casein was increased with the increase in ECG concentration. When the ECG concentration was at $20 \mathrm{mM}, 83 \%$ of the relative activity of caseinase and $57 \%$ of the relative activity of collagenase remained. The hydrolyzing capacity of proteinase $\mathrm{K}$ to casein was limited influenced by the introduction of gallate; over $95 \%$ of the relative activity of caseinase could be maintained with a gallate concentration of $1.0-20 \mathrm{mM}$. The activity of proteinase $\mathrm{K}$ to collagen fiber decreased with the increase in gallate; with $20 \mathrm{mM}$ gallate in the enzyme system, $45 \%$ of the relative activity of the collagenase component was prevented. The inhibition effect of gallate to protease $\mathrm{K}$ is possibly due to its combination with enzymes by hydrogen bonds and hydrophobic interactions [32]. This result illustrated that gallate could be applied for the unhairing processes to reduce the risk of grain damage.
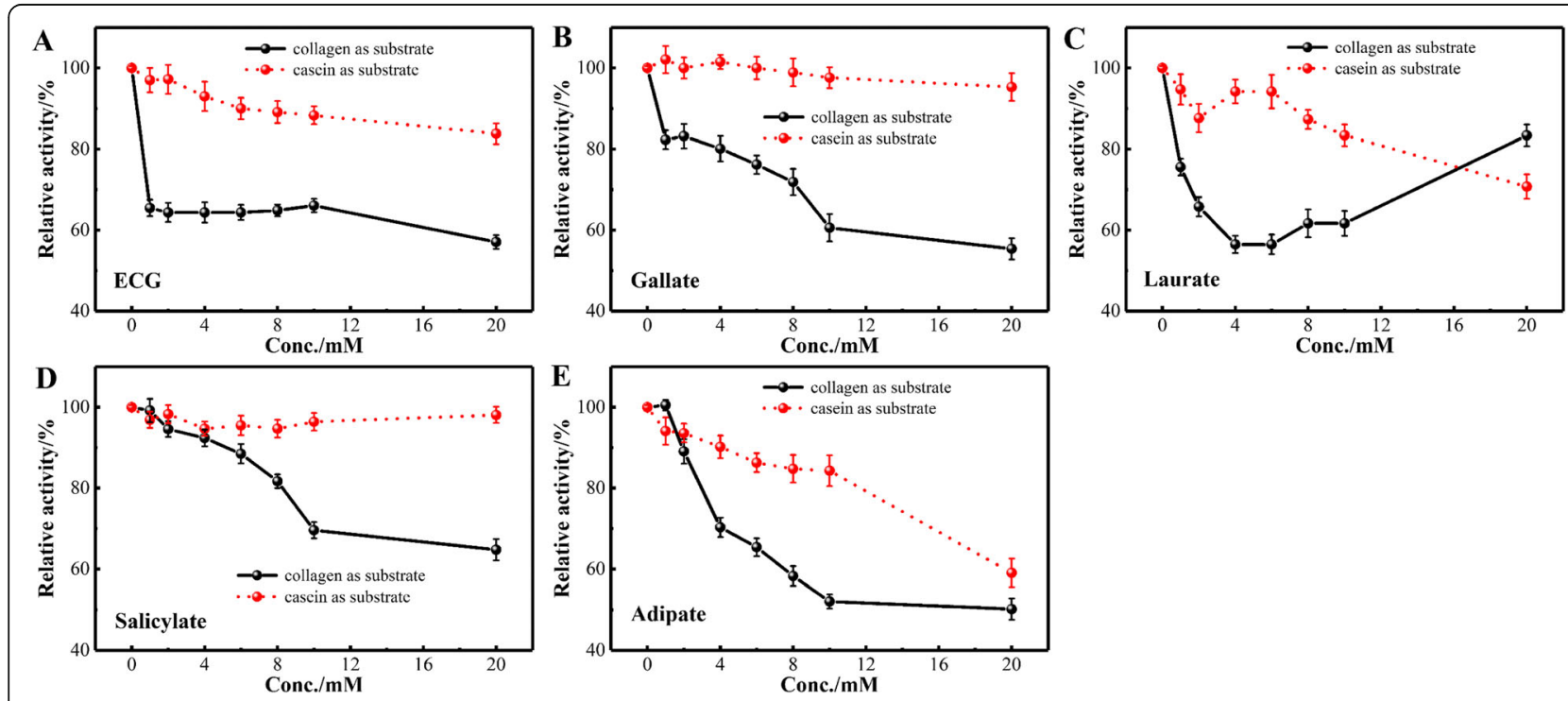

Fig. 2 The effect of organic additives on the hydrolytic activity of proteinase $\mathrm{K}$ 
Table 1 The effect of the additives on the hydrolytic activity of proteinase $\mathrm{K}$

\begin{tabular}{llll}
\hline Additives & $\begin{array}{l}\text { Conc. } \\
\text { /mM }\end{array}$ & \multicolumn{2}{l}{ Relative activity $/ \%$} \\
\cline { 3 - 4 } & & Collagen fiber & Casein \\
\hline Fe(III) & 2.0 & $67.0 \pm 0.8$ & $115.0 \pm 2.2$ \\
$\mathrm{Cu}(\mathrm{II})$ & 6.0 & $38.1 \pm 1.2$ & $91.5 \pm 1.6$ \\
$\mathrm{Al}(\mathrm{III})$ & 4.0 & $65.0 \pm 2.1$ & $85.7 \pm 0.7$ \\
Salicylate & 20.0 & $64.8 \pm 1.7$ & $98.1 \pm 1.4$ \\
Adipate & 10.0 & $51.8 \pm 0.6$ & $81.3 \pm 0.7$ \\
Laurate & 6.0 & $56.5 \pm 1.4$ & $94.2 \pm 1.5$ \\
Gallate & 20.0 & $55.4 \pm 0.3$ & $95.3 \pm 3.8$ \\
Epicatechin & 20.0 & $57.1 \pm 1.2$ & $81.8 \pm 2.1$ \\
\hline
\end{tabular}

The addition of salicylate only prevented $5 \%$ hydrolytic activity of proteinase $\mathrm{K}$ to casein, while hydrolytic activity on the collagen fiber was gradually reduced with the increase in salicylate. Only $64.8 \%$ of the relative activity of collagenase component remained when the concentration of salicylate was $20 \mathrm{mM}$ in the enzyme system. The activities of proteinase $\mathrm{K}$ for hydrolyzing both casein and collagen fibers were inhibited by the addition of adipate. When the concentration of adipate was less than $10 \mathrm{mM}$, the inhibition effect on the collagenase component was more significant than that of the caseinase component. When the concentration of adipate was higher than $10 \mathrm{mM}$, the activity of caseinase decreased more sharply than that of collagenase. When the concentration of adipate was $10 \mathrm{mM}$, approximately $50 \%$ (collagenase) and $85 \%$ (caseinase) of relative activities remained. The hydrolytic activity of proteinase $\mathrm{K}$ to collagen fiber was gradually inhibited when increasing the concentration of laurate to $6.0 \mathrm{mM}$; after that, the inhibition effect slowed down. Laurate also showed an inhibition effect on the caseinase component of proteinase K; when the concentration of laurate was below $6.0 \mathrm{mM}$, $95 \%$ of the relative activity of caseinase was reserved.
Both metal ions and organic additives that showed potential to reduce the risk of grain damage on enzymatic unhairing are summarized in Table 1.

\subsection{Enzymatic unharing by proteinase $\mathrm{K}$ with additives}

The unhairing processes of bovine hide by proteinase $\mathrm{K}$ with a certain concentration of the screened additives were performed with a $150 \mathrm{U} / \mathrm{g}$ hide of proteinase $\mathrm{K}$ at $35^{\circ} \mathrm{C}$ and $\mathrm{pH} 8.0$. The processing parameters and unhairing results are provided in Table 2. During the enzymatic unhairing process, the float was taken out periodically to determine the content of TP and Hyp. The results are shown in Figs. 3 and 4. For the addition of metal ions, the amount of TP in the float of the Fe(III) added unhairing was higher than that of the control (Fig. 3a), which followed the result where the addition of $2.0 \mathrm{mM} \mathrm{Fe}(\mathrm{III})$ in proteinase $\mathrm{K}$ system activated its hydrolytic activity to casein. However, the TP content in the enzymatic unhairing float with $\mathrm{Cu}(\mathrm{II})$ and $\mathrm{Al}(\mathrm{III})$ ions was lower than that of the control. This was due to the hydrolytic activity to casein of proteinase $\mathrm{K}$ being hindered by the addition of $\mathrm{Cu}(\mathrm{II})$ and $\mathrm{Al}(\mathrm{III})$, while being activated by the addition of Fe(III). The hydrolytic activity of caseinase plays a main role in unhairing speed [12]. The content of Hyp in the solution of the added $\mathrm{Fe}(\mathrm{III}), \mathrm{Cu}(\mathrm{II})$ and $\mathrm{Al}(\mathrm{III})$ was lower than in the control (Fig. 3b). This could be explained tby all three metal ions having an inhibition effect on the collagenase component. Compared with the two other ions, the Hyp content with the addition of $\mathrm{Fe}(\mathrm{III})$ in the enzymatic unhairing system was very close to that of the control system because the inhibition effect of $2.0 \mathrm{mM} \mathrm{Fe}(\mathrm{III})$ on collagenase was the least between the three systems.

The TP and Hyp profiles of the unhairing float with organic additives are shown in Fig. 4. The results showed that the contents of TP and Hyp in the enzymatic unhairing float by the addition of ECG were lower than those of the control sample, illustrating that ECG can inhibit the

Table 2 The results of enzymatic unhairing by proteinase $\mathrm{K}\left(150 \mathrm{U} / \mathrm{g}\right.$ hide) with additives at $35^{\circ} \mathrm{C}, \mathrm{pH} 8.0$

\begin{tabular}{llll}
\hline No. & Unhairing procedures & Time for unhairing & Damage level of grain and hair pores \\
\hline 1 & Proteinase $\mathrm{K}$ & $5.0 \mathrm{~h}$, completely unhaired & +++++ \\
2 & Proteinase $\mathrm{K}+2.0 \mathrm{mM} \mathrm{Fe}(\mathrm{III})$ & $5.0 \mathrm{~h}$, completely unhaired & +++ \\
3 & Proteinase $\mathrm{K}+6.0 \mathrm{mM} \mathrm{Cu}(\mathrm{II})$ & $7.0 \mathrm{~h}$, completely unhaired & ++ \\
4 & Proteinase $\mathrm{K}+4.0 \mathrm{mM} \mathrm{Al}(\mathrm{III})$ & $5.0 \mathrm{~h}$, completely unhaired & ++ \\
5 & Proteinase $\mathrm{K}+20 \mathrm{mM}$ Salicylate & $4.5 \mathrm{~h}$, completely unhaired & ++ \\
6 & Proteinase $\mathrm{K}+10 \mathrm{mM}$ Adipate & $7.0 \mathrm{~h}$, completely unhaired & +++ \\
8 & Proteinase $\mathrm{K}+6.0 \mathrm{mM}$ Laurate & $6.0 \mathrm{~h}$, completely unhaired & ++ \\
9 & Proteinase $\mathrm{K}+20 \mathrm{mM} \mathrm{Gallate}$ & $10.0 \mathrm{~h} 90 \%$ hair removed & + \\
\hline
\end{tabular}

Using the unhaired sample by proteinase $\mathrm{K}$ as control, define its damage level of grain and hair as +++++ level, the less the + level, the less the grain damage 

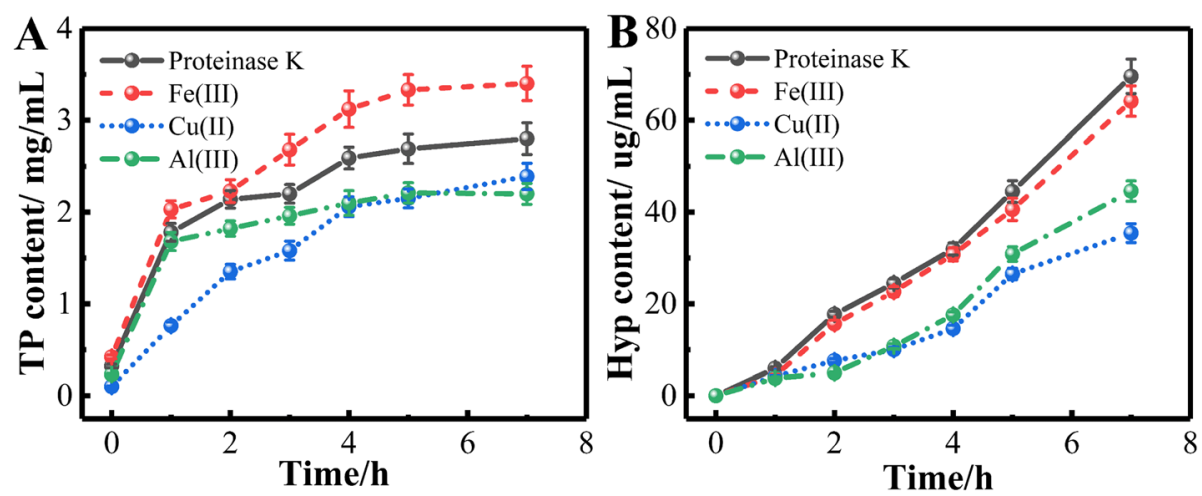

Fig. 3 Hyp and Total protein content in the float during enzymatic unhairing by adding metal ions

activities of proteinase $\mathrm{K}$ during the unhairing process. These results were followed by the unhairing rate being reduced by ECG. The chemical composition of ECG is a poly-phenol similar to vegetable tannins that can react with hides, thus imparting the hide with leather like grains and hindering its hydrolysis $[19,33]$. The TP and Hyp profiles of the addition of the gallate sample were at the same level as those of the control(unhairing by proteinase $\mathrm{K}$ without additives) during the first $10 \mathrm{~h}$ (Fig. 4). This indicated that gallate had little effect on the inhibition of proteinase $\mathrm{K}$ during the unhairing process. Furthermore, in comparison with the control sample, the addition of the other organic additives in the proteinase $\mathrm{K}$ unhairing process reduced Hyp content, but increased TP content in the float. This indicated that the addition of these additives not only maintains the unhairing speed but also reduces the excessive hydrolysis risk of collagen.

Grain appearance images after hair removal are shown in Fig. 5. For the addition of metal ions in the enzymatic unhairing process, $4.0 \mathrm{mM} \mathrm{Al}(\mathrm{III})$ and $2.0 \mathrm{mM} \mathrm{Fe}(\mathrm{III})$ produced an insignificant decrease in the unhairing speed. The hair was mostly removed after $3 \mathrm{~h}$ of treatment. The whole enzymatic unhairing process by adding $\mathrm{Al}(\mathrm{III})$ and $\mathrm{Fe}(\mathrm{III})$ was accomplished within $5 \mathrm{~h}$, which was as fast as the control, and no fine hairs remained on the pelt (Fig. 5b, c). During enzymatic unhairing by the addition of $\mathrm{Cu}(\mathrm{II})(6.0 \mathrm{mM})$, numerous hairs remained, and only part of them could be removed by hand after $3 \mathrm{~h}$; the whole unhairing process required $7 \mathrm{~h}$ until fine hairs could be removed.

The enzymatic unhairing rate was accelerated by the addition of laurate and salicylate. The enzymatic unhairing process was accomplished in $4.5 \mathrm{~h}$ without tiny hairs remaining on the pelt. However, adipate addition reduced the enzymatic unhairing rate. More than $50 \%$ of the hairs remained, and the hair roots were tight after three hours of the process. We noted that the enzymatic unhairing process was slowed down by the addition of gallate and epicatechin. The unhairing process was extended to $10 \mathrm{~h}$ with the addition of gallate; with the addition of epicatechin, even with $20 \mathrm{~h}$ of enzymatic treatment, some hairs remained afterward (Fig. 5h). After chrome tanned, the appearance of the grains and the hair pores of the wet blue were observed by stereo microscope (Fig. 6). The damage on the grain surface was clearly observed (dash) on the control sample (Fig. 6i). Grain damage was apparently less for samples with the addition of all additives. The samples that were enzymatically unhaired with the addition of
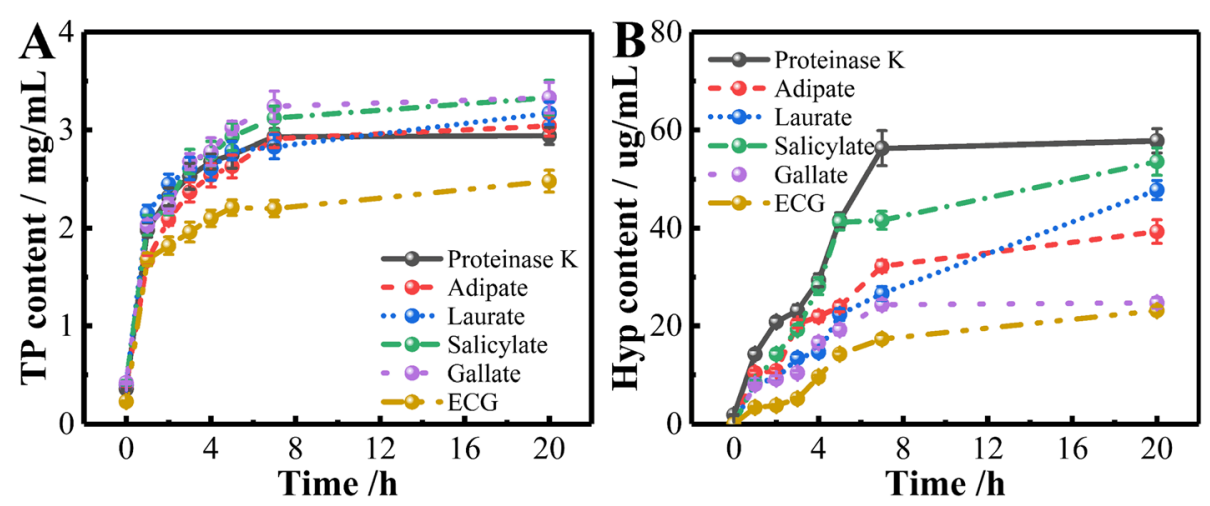

Fig. 4 Hyp and Total protein content in the float during enzymatic unhairing by adding organic additives 


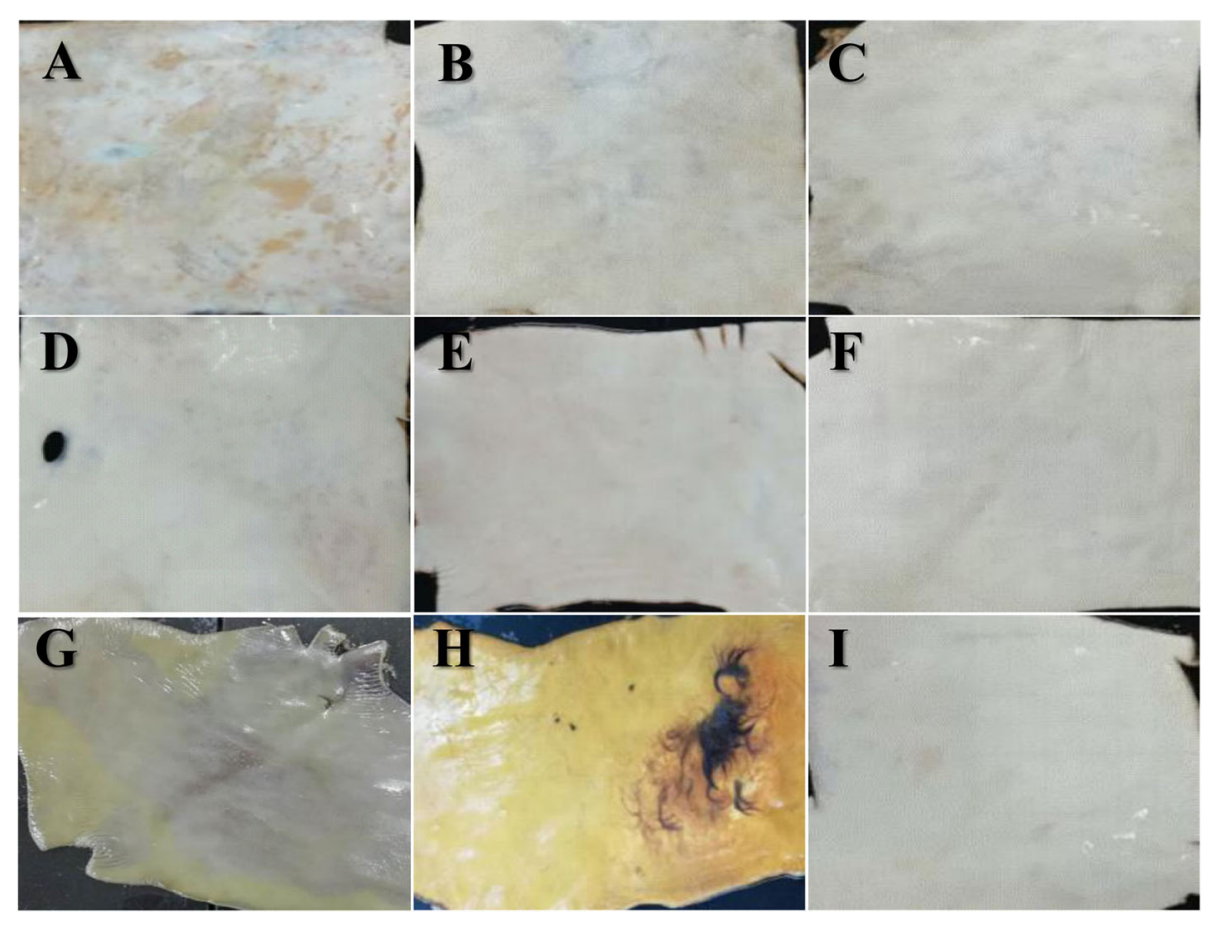

Fig. 5 The appearance of unhaired pelt by digital camera. (a Cu(II); b Al(III); c Fe(III); d Adipate; e Laurate; f Salicylate; $\mathbf{g}$ Gallate; $\mathbf{h}$ ECG; i Proteinase K)

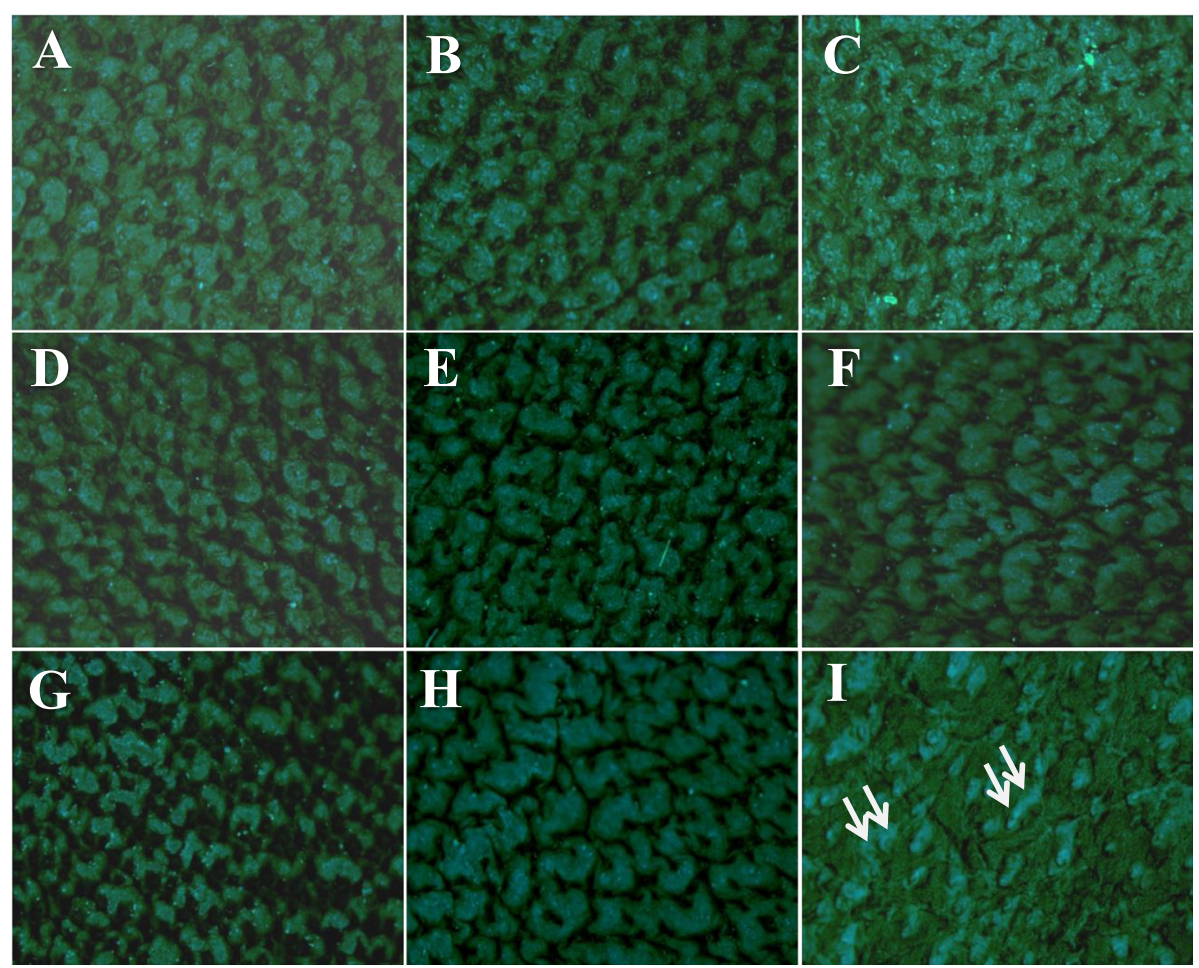

Fig. $\mathbf{6}$ The stereo-microscope profiles of the crust after unhairing (a Cu(II); b Al(III); $\mathbf{c}$ Fe(III); $\mathbf{d}$ adipate; e salicylate; $\mathbf{f}$ laurate; $\mathbf{g}$ Gallate; $\mathbf{h}$ ECG; i Proteinase K) 


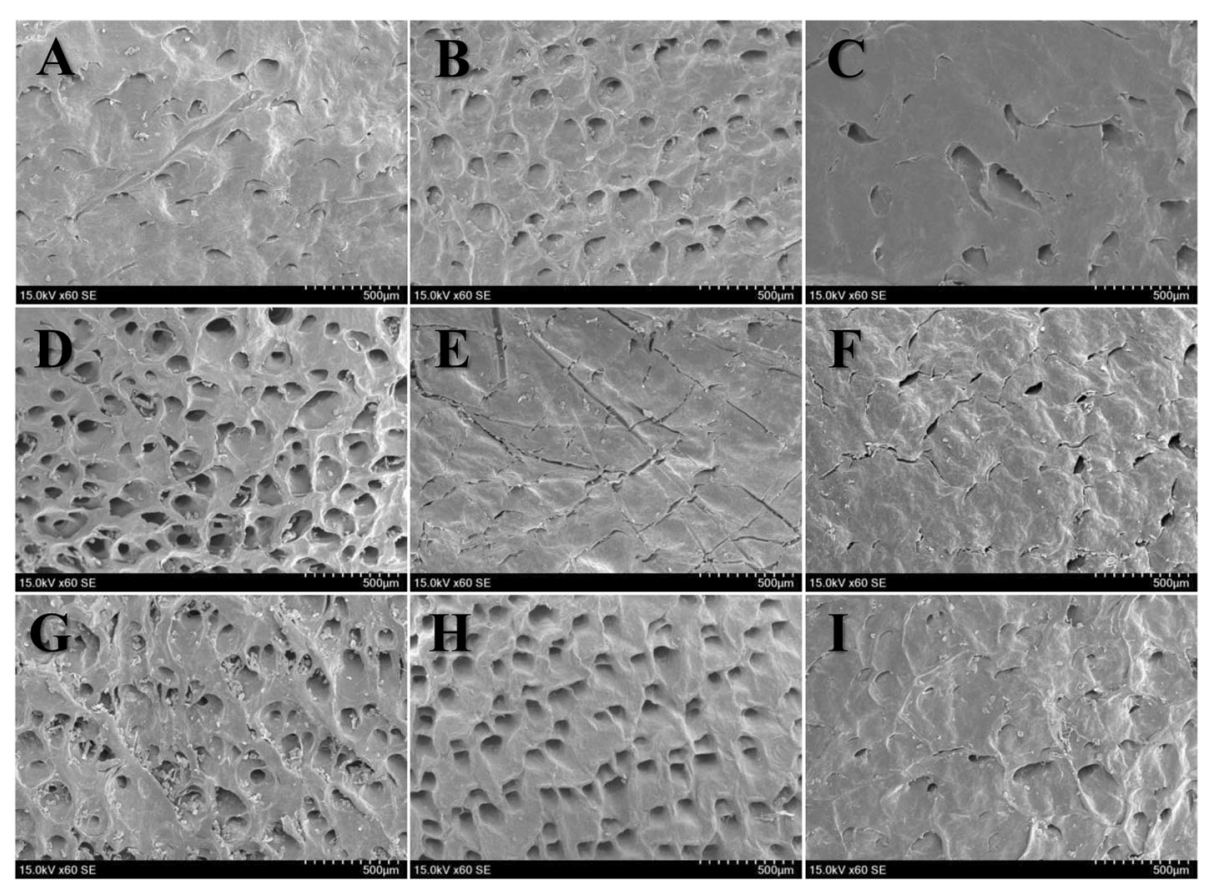

Fig. 7 SEM images of grain. (a Cu(II); b Al(III); c Fe(III); $\mathbf{d}$ adipate; e salicylate; $\mathbf{f}$ laurate; $\mathbf{g}$ Gallate; $\mathbf{h}$ ECG; i Proteinase K)

ECG showed clear grains and hair pores, with a very rough grain texture (Fig. 6h). In comparison with other additives, with the addition of $\mathrm{Fe}(\mathrm{III})$ and adipate, some grain damage was still observed (Fig. 6c, d). The formaldehyde fixed enzymatic unhairing pelts were lyophilized and then observed by SEM (Fig. 7). The SEM images showed that the grain morphology of the samples enzymatically unhaired with additives was much clearer, and grain damage appeared to be less compared with that of the control sample (Fig. 7i). The results illustrated that the risk of grain damage from enzymatic unhairing by proteinase $\mathrm{K}$ could be reduced by adding the screened additives. The unhairing rate by proteinase $\mathrm{K}$ is especially unaffected by the addition of a suitable concentration of $\mathrm{Al}(\mathrm{III})$, salucylate, and laurate.

\section{Conclusions}

In this study, additives including metal ions and organic agents were screened and applied to decrease the risk of grain damage during enzymatic unhairing by proteinase $\mathrm{K}$. we concluded that the addition of $\mathrm{Cu}(\mathrm{II})((6.0 \mathrm{mM})$, $\mathrm{Al}(\mathrm{III})(4.0 \mathrm{mM})$ and $\mathrm{Fe}(\mathrm{III})(2.0 \mathrm{mM})$ in a proteinase $\mathrm{K}$ system could inhibit $33 \%$ of hydrolytic activity on collagen fibers, while its hydrolytic activity for casein was maintained to a the level at least $85 \%$. The addition of organic additives salicylate $(20.0 \mathrm{mM})$, adipate $(10.0 \mathrm{mM})$, laurate $(6.0 \mathrm{mM})$ gallate $(20.0 \mathrm{mM})$ and ECG $(20.0 \mathrm{mM})$ in the proteinase $\mathrm{K}$ system could inhibit hydrolytic activity to collagen fibers by at least 35\%, while its hydrolytic activity to casein remained at least at $80 \%$. The metal ions and organic additives were applied to bovine hide enzymatic unhairing with proteinase $\mathrm{K}$, of which the hydrolytic activities to collagen fibers were noticeably lessened. The unhairing rate by proteinase $\mathrm{K}$ was uninfluenced by the addition of a suitable concentration of $\mathrm{Al}(\mathrm{III})$, salicylate, and laurate. The results revealed that the addition of a suitable amount of the screened additives could avoid excessive hydrolysis of collagen fibers and grain damage in enzymatic unhairing could be improved by adding the screened additives.

\section{Abbreviations \\ TP: Total protein; Hyp: Hydroxyproline; BSA: Bovine serum albumin; SEM: Scanning electron microscope; ECG: Epicatechin; U: Unit of enzymatic activity}

\section{Acknowledgements \\ Not applicable.}

\section{Authors' contributions}

$M C$ performed the experiments about the screening of metal ions and unhairing process, and was a major contributor in data analyses and writing the manuscript. MFJ performed the experiments about the screening of organic additives and data analyses and writing the manuscript. HL performed the experiments about morphology determination and data analyses. HMC performed the revision of the manuscript. All authors read and approved the final manuscript.

\section{Funding}

This work was financially supported by the National Key Technology Research and Development Program of China (2017YFB0308400).

\section{Availability of data and materials}

All data needed to evaluate the conclusions in the paper are presented in the paper. 


\section{Competing interests}

The authors declare no competing interest.

\section{Author details}

${ }^{1}$ Key Laboratory of Leather Chemistry and Engineering of Ministry of Education, Sichuan University, Chengdu 610065, China. ${ }^{2}$ Chengdu Technological University, Chengdu 611730, China. ${ }^{3}$ National Engineering Laboratory for Clean Technology of Leather Manufacture, Sichuan University, Chengdu 610065, China.

Received: 19 March 2020 Accepted: 3 July 2020

Published online: 09 October 2020

\section{References}

1. Sujitha P, Kavitha S, Shakilanishi S, Babu NKC, Shanthi C. Enzymatic dehairing: a comprehensive review on the mechanistic aspects with emphasis on enzyme specificity. Intern J Biol Macromol. 2018;118:168-79.

2. Christopher JG, Ganesh S, Palanivel S, Ranganathan M, Jonnalagadda RR. Cohesive system for enzymatic unhairing and fibre opening: an architecture towards eco-benign pretanning operation. J Clean Prod. 2014;83:428-36.

3. Song Y, Wu S, Yang Q, Liu H, Zeng Y, Shi B. Factors affecting mass transfer of protease in pelt during enzymatic bating process. J Leather Sci Eng. 2019;1:4.

4. Anzani C, Prandi B, Buhler S, Tedeschi T, Baldinelli C, Sorlini G, Dossena A, Sforza S. Towards environmentally friendly skin unhairing process: a comparison between enzymatic and oxidative methods and analysis of the protein fraction of the related wastewaters. J Clean Prod. 2017;164:1446-54.

5. Dettmer A, Cavalheiro JC, Cavalli E, Misturini RD, de Souza GC, Zachia AMA, Gutterres M. Optimization of the biotechnological process for hide unhairing in substitution of toxic sulfides. Chem Eng Technol. 2012;35:80310.

6. Fang Z, Yong Y-C, Zhang J, Du G, Chen J. Keratinolytic protease: a green biocatalyst for leather industry. Appl Microb Biotech. 2017;101(21):7771-9.

7. Virgilijus $V$, Kestutis $B$, Violeta $V$. An approach to cleaner production: from hair burning to hair saving using a lime-free unhairing system. J Clean Prod. 2009;17:214-21.

8. Gao X-L, Liu Y, Wang R, Chen M, Cheng H-M, Li Z-Q. Study on the enzymatic unhairing on cattle hide at low temperature. Leather Sci Technol. 2011;21:47-51.

9. Cheng H-M, Xu X-H, He X-X, Chen M, Li Z-Q. A new approach of enzymatic unhairing process on cattle hide. In: Proceedings of the XXXII Congress of IULTCS, Turkey; 2013.

10. Wang R, Li Z-Q, Chen M, Cheng H-M. Isolation and purification of caseinase and collagenase from commercial bacillus subtilis AS1.398 enzyme by affinity chromatography. J Soc Leather Technol Chem. 2009;93:8-11.

11. Murphy $\mathrm{G}$, Nagase $\mathrm{H}$. Progress in matrix metalloproteinase research. Mol Asp Med. 2008;29(5):290-308.

12. Li Z-Q, Zhang N-S, Yin X-Y. Study on the effect and evaluation of the different compositions of enzyme preparations on unhairing process. China Leather. 1996;25(6):10-4.

13. He X-X, Cheng H-M, Chen M, Li Z-Q. Epidermis morphology investigation of cattle hide during unhairing process by transimission electron microscope. J Soc Leather Technol Chem. 2012;96(3):119-22.

14. Chen $M$, Jiang M-F, Chen M, Cheng H-M. Approach towards safe and efficient enzymatic unhairing of bovine hides. J Am Leather Chem Assoc. 2018;113(2):59-64.

15. Barrantes E. Inhibition of collagenase and metalloproteinases by aloins and aloe gel. Life Sci. 2003;72:843-50.

16. Ulies M, Banciu DM, Scozzafava A, llies MA, Caproiu MT, Supuran CT. Protease inhibitors: synthesis of bacterial collagenase and matrix metalloproteinase inhibitors incorporating arylsulfonylureido and 5-Dibenzo-suberenyl/suberyl moieties. Bioorg Med Chem Lett. 2003;11:2227-39.

17. Scozzafava A, Supuran TC. Protease inhibitors: synthesis of matrix metalloproteinase and bacterial collagenase inhibitors incorporating 5Amino-2-mercapto-1,3,4-thiadiazole zinc binding functions. Bioorg Med Chem Lett. 2002:12:2667-72.

18. Zhang J, Li T, Lu T, Meng W, Yu D-N, Chen Y-D. Theoretical studies on the mechanisms of interaction between morin and the catalytic zinc ion in matrix metalloproteinases. Acta Chim Sin. 2011;69(3):253-61.

19. Jackson J-K, Zhao J-Y, Wong W. The inhibition of collagenase induced degradation of collagen by the galloyl-containing polyphenols tannic acid, epigallocatechin gallate and epicatechin gallate. J Mater Sci Mater Med. 2010;21(5):1435-43.

20. Jovanovic A, Ermis R, Mewaldt R, Shi L, Carson D. The influence of metal salts, surfactants, and wound care products on enzymatic activity of collagenase, the wound debriding enzyme. Wounds. 2012;24:242-53.

21. Schirmeister T. Metal ions as co-inhibitors of serine proteases: a new approach in the search for specific high-affinity ligands. Angew Chem Int Ed. 1998:37(13-14):1830-2.

22. Jany KD, Mayer B. Proteinase $\mathrm{K}$ from Tritirachium album limber. I. Molecular mass and sequence around the active site serine residue. Biol Chem. 1985; 366(5):485-92.

23. Gunkel FA, Gassen HG. Proteinase K from Tritirachium album Limber. Characterization of the chromosomal gene and expression of the cDNA in Escherichia coli. Eur J Biochem. 1989;179(1):185-94.

24. Bajorath J, Saenger W, Pal GP. Autolysis and inhibition of Proteinase K, a subtilisin-related serine proteinase isolated from the fungus Tritirachium album Limber. Biochem Biophys. 1988;954(2):176-82

25. Pan J. Leather Analysis Manual. Beijing: Light Industry Press; 1988. p. 80-8.

26. Lowry OH, Rosebrough NJ, Farr AL, Randall RJ. Protein measurement with the Folin phenol reagent. J Biol Chem. 1951;193(1):265-75.

27. Bergman I, Loxley R. Two improved and simplified methods for the spectrophotometric determination of hydroxyproline. Anal Chem. 1963; 35(12):1961-5

28. Hashida $Y$, Inouye K. Kinetic analysis of the activation-and-inhibition dual effects of cobalt ion on thermolysin activity. J Biochem. 2007;141(6):843-53.

29. Betzel C, Pal PG, Saenger $W$. Three-dimensional structure of proteinase $K$ at 0.15-nm resolution. Eur 3 Biochem. 1988;178:155-71.

30. Hemmadi V, Das A, Chouhan OP, Biswas S, Biswas M. Effect of ions and inhibitors on the catalytic activity and structural stability of $S$. aureus enolase. J Biosci. 2019;44(90):1-14.

31. Wang S, Lv M, Yang J, Zhou Y, Xu B. Effects and mechanism of metal ions on enzymatic hydrolysis of wheat straw after pretreatment. Bioresources. 2018:13(2):2617-31.

32. Krishnamoorthy G, Sehgal PK, Mandal AB, Sadulla S. Studies on collagentannic acid-collagenase ternary system: inhibition of collagenase against collagenolytic degradation of extracellular matrix component of collagen. J Enzyme Inhib Med Chem. 2012:27(3):451-7.

33. Shi $B$, He X-Q, Zhang D-X, Haslam E. Studies on vegetable tannin-collagen interaction. China Leather. 1993:22(8):26-31.

\section{Publisher's Note}

Springer Nature remains neutral with regard to jurisdictional claims in published maps and institutional affiliations.

\section{Submit your manuscript to a SpringerOpen ${ }^{\circ}$ journal and benefit from:}

- Convenient online submission

- Rigorous peer review

- Open access: articles freely available online

- High visibility within the field

- Retaining the copyright to your article

Submit your next manuscript at $>$ springeropen.com 